\title{
Pemberdayaan Masjid di Indonesia dalam Perspektif Intitutional Building
}

\author{
Rita Sukma Dewi ${ }^{\text {a }}$ \\ ${ }^{a}$ Kementrian Agama Republik Indonesia
}

\section{INFORMASI ARTIKEL}

\section{Article history:}

Dikirim tanggal: 02 November 2018

Revisi pertama tanggal: 02 Januari 2019

Diterima tanggal: 26 Maret 2019

Tersedia online tanggal: 23 April 2019

Keywords: empowerment, mosque, institutional building, development, capacity building, islam

\section{ABSTRACT}

The development of the religious field is believed to be an alternative solution to the choices of development strategies. Assuming that religion always leads to goodness, the offer of development based on religious values is always interesting to explore. The mosque as a religious institution turned out to have the potential as a community empowerment institution. With the function embedded in it, the mosque is not only used for the sake of worship but also carries out several social functions such as education, culture and even the economy. Mosques has discovered to be a social capital to improve the development of Indonesian society. The aims of this research is the first, to describe the elements of mosque empowerment as an institution. Second, to determined mosque empowerment efforts carried out by the government.

\section{INTISARI}

Pembangunan bidang agama diyakini sebagai sebuah alternatif solusi bagi pilihanpilihan strategi pembangunan di Indonesia. Dengan asumsi bahwa agama selalu membawa ke arah kebaikan, maka alternatif strategi pembangunan berbasis nilainilai keagamaan selalu menarik untuk dijajaki. Pemberdayaan masjid belakangan dibaca sebagai "potensi" untuk membangun masyarakat ke arah peradaban masyarakat madani. Masjid dengan fungsi yang dibenamkan kepadanya yang bukan hanya digunakan untuk kepentingan ibadah namun juga melaksanakan fungsifungsi sosial lainnya seperti pendidikan, kebudayaan, sosial kemasyarakatan bahkan ekonomi diyakini sebagai modal sosial pembangunan masyarakat indonesia. Penelitian ini bertujuan untuk pertama, mendeskripsikan unsur-unsur masjid sebagai sebuah lembaga. Kedua, upaya pemberdayaan masjid sebagai sebuah lembaga yang dilakukan oleh pemerintah.

\section{Pendahuluan}

Sebagai bangsa yang religius, Indonesia memiliki cita-cita membangun masyarakat menjadi masyarakat sejahtera yang tidak hanya sejahtera lahiriyah tapi juga sejahtera secara bathiniyah. Indikator-indikator sejahtera lahiriyah telah memiliki indikator yang disepakati oleh khalayak ramai sebut saja pendapatan perkapita, derajat konsumsi, derajat produksi dan kesempatan kerja (Kartasasmita, 1996). Sebaliknya bagaimana mengukur kesejahteraan bathiniyah selalu menjadi diskursus yang menarik.

Fenomena yang terjadi dimasyarakat hari ini makin menjauhkan cita-cita kesejahteraan bathiniyah dari realisasinya. Norma dan etika yang meluntur, musyawarah mufakat yang semakin dihindari, nilai-nilai 
kebersamaan dan gotong royong yang semakin terkikis dengan individualisme khas mayarakat modern, agama yang dilaksanakaan sebatas ritual dengan makna yang kosong menjadi serangkaian indikator ketidaksejahteraan masyarakat Indonesia secara bathin sekaligus kegagalan pembangunan dari sisi pembangunan non-fisik.

Pemerintah bersama masyarakat terus mengkaji upaya memperbaiki keadaan tersebut. Para penyuluhpenyuluh agama tak henti-hentinya berseru kepada perbaikan moral namun tak jarang juga contoh sebaliknya mereka pertontonkan. Ketokohan nampaknya tidak lagi "manjur" dalam tipe masyarakat yang semakin kritis dan selektif sekarang ini. Perlu strategi yang lebih massive dan sistemik dalam penanganan masalah pembangunan karakter bangsa ini.

Masjid adalah sebuah simbol dimana hanya hal-hal baik, hal-hal positif yang akan muncul pada pemikiran setiap orang kala menyebut kata "masjid" terutama dikalangan masyarakat muslim. Selain menjadi simbol nilai-nilai positif ternyata masjid menyimpan potensi yang lebih besar dari itu.

Contoh-contoh success story masjid yang sukses tidak hanya memberdayakan dirinya, memandirikan dirinya tapi juga berhasil membangun peradaban masyarakat di sekitarnya, semakin membuktikan bahwa masjid merupakan social capital yang dimiliki oleh bangsa Indonesia. Akan tetapi potensi yang begitu besar ini menjadi redup saat masjid tidak mendapat penanganan sebagaimana mestinya.

Tabel 1 Data Perkembangan Jumlah Masjid

\begin{tabular}{|l|c|c|c|c|c|}
\hline \multicolumn{1}{|c|}{ Tahun } & 2009 & 2010 & 2011 & 2012 & 2013 \\
\hline Masjid & 163.759 & 279.516 & 283.859 & 288.951 & 289.951 \\
\hline Mushalla & 245.639 & 419.274 & 425.789 & 432.176 & 527.657 \\
\hline Total & 409.398 & 698.790 & 709.648 & 720.293 & 817.608 \\
\hline
\end{tabular}

Sumber: Kemenag RI, 2016

Namun perkembangan yang menggembirakan dari sisi jumlah tersebut tidak diimbangi dengan kabar menggembirakan dari sisi keberfungsian masjid. Bahkan kondisi yang lebih memprihatinkan akhir-akhir ini justru masjid beberapa kali diperlihatkan sebagai sosok yang antagonis dengan pergumulan retorika dakwah yang makin berjarak dari masyarakat, makin jauh dari nilainilai keberagamaan yang agung.

Berangkat dari keprihatinan ini Kemenag menyusun serangkaian strategi pemberdayaan masjid, dengan tujuan agar masjid-masjid di Indonesia kembali pada fungsi awalnya masjid didirikan, yaitu bukan hanya fungsi ibadah saja (mahdlah) melainkan juga melaksanakan fungsi-fungsi ibadah sosial (ghairu mahdlah) lainnya seperti pendidikan, kesehatan, sosial, budaya, ekonomi dan urusan-urusan kemasyarakatan lainnya. Masjid juga diangankan dapat menjadi kantongkantong pemberdayaan masyarakat secara ekonomi yang dapat memberikan kontribusi pada target pembangunan nasional.
Penelitian ini bertujuan untuk mendeskripsikan unsur-unsur masjid sebagai sebuah lembaga yang memenuhi kriteria pembangunan kelembagaan. Penelitian ini juga bertujuan untuk menganalisa strategi pemberdayaan masjid yang telah dilakukan oleh pemerintah dalam hal ini Kemenag dalam tinjauan pembangunan kelembagaan.

\section{Teori}

\subsection{Pembangunan dan Administrsi}

Pembangunan secara sederhana dipahami umum sebagai proses perubahan yang dilakukan konsisten terus-menerus menuju keadaan yang lebih baik berdasarkan kesepakatan yang diterima luas atau norma tertentu. Pembangunan dapat juga dipahami sebagai sebuah proses untuk melakukan perubahan (Bratakusumah \& Riyadi, 2005).

Serangkaian usaha untuk tumbuh dan mengalami perubahan yaitu perubahan yang terencana, dilakukan secara sadar oleh pemerintah mewakili bangsa dan negara sebagai upaya pembina negara ke arah modern (nation building)(Siagian, 1994).

Pengertian lainnya mengartikan pembangunan sebagai sebuah pergerakan, bertransformasi dalam bidang-bidang kajian ekonomi, sosial dan budaya yang mana pergerakan itu dilakukan secara sengaja. Bentuk kesengajaan tersebut dapat dilihat dari kebijakan yang diluncurkan sebagai strategi pencapaian cita-cita yang diinginkan (Tikson, 2005).

Diantara gambaran positif tentang cita-cita pembangunan, pembangunan juga memiliki sisi kelam yang bentuknya bukan hanya kegagalan proses pembangunan itu sendiri mencapai tujuannya namun kesenjangan atau disparitas atau gap yang muncul akibat pembangunan terlalu berorientasi pada indikator ekonomi bentuknya antara lain marginalisasi, eksploitasi, dan jurang kemiskinan. Untuk merespon adanya kesenjangan hasil pembangunan tersebut maka muncul paradigma pembangunan yang tidak sekedar bertumpu pada pertumbuhan namun juga pada pemerataan pembangunan dan hasil-hasilnya (growth and equity) dengan berorientasi pada pembangunan manusia (human center development).

Ide dan usaha mengembangkan prinsip-prinsip administrasi pembangunan mulai muncul pasca perang dunia II (1960-an) didorong oleh dua faktor utama: Pertama, kebutuhan dari negara-negara yang menang perang untuk membantu membangun kembali kondisi negara akibat kelelahan dalam perang. Kedua, adanya pengalaman negara-negara maju yang berhasil membantu pembangunan di Eropa tapi tidak berhasil membantu pembangunan dinegara-negara berkembang (Mindarti, 2007:146). 
Alur pemikiran administrasi pembangunan kemudian berkembang kedalam empat aras atau alur: Pertama, aras pembaharuan administratif (administrative reform), yaitu penggunaan prinsip-prinsip administrasi publik dengan memperhatikan berbagai konteks administrasi dan kondisi lingkungan yang dapat mempengaruhi kemampuan untuk melaksanakan pembangunan. Kedua, aras pembangunan institusi (institutional building). Esman (1972) sebagaimana dikutip dalam Haryono (2012:34) mengemukakan:

Institution building is a perspective on planned and guided changes. In norms, in behaviour pattern, in individual and group relationship, in new perspeception of goals as well as means.

Ketiga, adalah aras studi kebijakan (policy reform) dengan tekanan pada analisa dan pembuatan kebijakan. Keempat, aras implementasi (Gabriel Iglesias, 1976):

The capacity of administrative systems to implement had been identified as a critical factor in the plan implementation process.

\subsection{Pembangunan Kelembagaan}

Pembangunan lembaga mengusulkan penggunaan seperangkat konsep atau abstraksi logika, yang mengidentifikasi variabel-variabel organisatoris dalam suatu proses sosial yang kompleks, seperti kepemimpinan dan doktrin. Konsep-konsep tersebut merupakan kumpulan pengertian (nomenklatur) yang berfungsi bagi peneliti untuk menjelaskan pengamatan-pengamatannya.
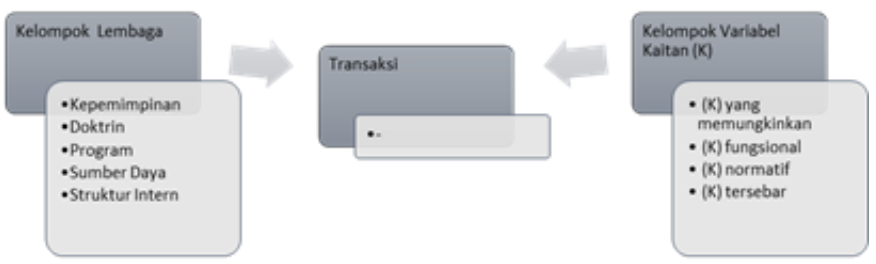

Gambar 2 Konsep Pembangunan Lembaga Sumber: Esman, 1986

Kelompok lembaga meliputi: (a) Kepemimpinan, diarahkan pada orang perorang maupun kelompok yang secara aktif terlibat dalam menyusun pengertian atas pengertian doktrin dan penyusunan program dari sebuah lembaga hingga mengarahkan kinerja lembaga tersebut beserta kaitan lembaga dengan lingkungannya; (b) Doktrin, diarahkan pada uraian nilai yang dianut oleh segenap anggota, seperangkat tujuan lembaga hingga bagaimana metode yang digunakan sebagai dasar tindakan sosial. Tema-tema yang terkandung dalam doktrin ini akan memproyeksikan baik kedalam (organisasi) sebagai values atau sebagai guide maupun ke lingkungan luar organisasi tersebut. Seperangkat citacita, image building dan harapan-harapan tentang mau dibawa kemana lembaga ini dengan tindakan seperti apa; (c) Program diarahkan pada keputusan atas tindakan yang dilakukan yang memiliki keterkaitan dengan pelaksanaan tusi lembaga. Program dapat juga dinyatakan sebagai output dari lembaga. Program adalah manifestasi dari doktrin yang berwujud menjadi pola-pola tindakan yang dilakukan secara nyata dan sadar dan menempatkan pospos sumberdaya dan kekuatan baik yang berasal dari internal lembaga maupun yang berasal dari eksternal lembaga; (d) yang dimaksud dengan sumber daya jenisnya sebagai berikut: memetakan kekuatan fisik yang dimiliki lembaga, keuangan, SDM, keterlibatan teknologi dan fungsi kehumasan dari lembaga tersebut. Unsur ini harus dianalisis sedemikian rupa agar dipastikan selalu keberadaanya dijamin dalam keadaan yang selalu tersedia secara handal dan mantap; dan (e) Kondisi struktur internal juga penting, sebuah lembaga harus memiliki struktur dan SOP untuk bekerjanya lembaga. Dalam struktur akan dibahas pembagian-pembagian peran, pembagian kewenangan, pola-pola komunikasi, sistem proses bekerja lembaga termasuk kepatuhan anggota terhadap doktrin dan juga program lembaga.

Kelompok kaitan meliputi: (a) Kaitan yang memungkinkan (enabling), yang termasuk dalam kaitan ini adalah hubungan antara lembaga dengan organisasiorganisasi atau kelompok-kelompok sosial yang punya kuasa atas pengendalian sumber-sumber daya dan penalokasian wewenang yang dibutuhkan sebuah lembaga untuk memenuhi fungsinya; (b) Kaitan fungsional, yaitu meliputi kaitan antara lembaga dengan organisasi-organisasi atau kelompok-kelompok sosial yang menyediakan input bagi lembaga dan di waktu yang sama membutuhkan output dari lembaga untuk menjadi input selanjutnya; (c) Kaitan normatif, yang termasuk dalam kaitan ini adalah hubungan antara lembaga dengan organisasi-organisasi atau kelompok-kelompok sosial yang memberikan nilai-nilai dan norma yang dibutuhkan bagi kelembagaan untuk mengimplementasikan doktrin dan program dari lembaga; dan d) kaitan tersebar, yaitu meliputi kaitan antara lembaga dengan organisasiorganisasi atau kelompok-kelompok sosial yang tidak bisa kita identifikasi keanggotaannya dalam organisasi formal namun memiliki kaitan dengan unsur-unsur di dalam komunitas.

\subsection{Pemberdayaan Masjid}

Pemberdayaan merupakan peristilahan yang berasal dari kata daya yang artinya tenaga atau kekuatan, lalu ditambah awalan ber- artinya menjadi memiliki tenaga, memiliki daya atau memiliki kekuatan. Pemberdayaan adalah usaha untuk meyusun sumber-sumberdaya menjadi sebuah konstruksi bangunan dengan cara mendorong, memotivasi, dan memberikan awareness tentang keberadaan potensi yang dimiliki dan kemungkinan untuk mengembangkannya (Mubyarto, 2000:263).

Pemberdayaan atau pengembangan adalah upaya memperluas horison pilihan bagi masyarakat 
(Machendrawati, 2001:30). Kegiatan pemberdayaan dapat didefinisikan sebagai kegiatan menyediaan semua sumberdaya yang dibutuhkan materiil maupun nonmateriil (soft skills dan knowledge) untuk meningkatkan kapasitas dari sebuah lembaga atau sekelompok masyarakat agar mereka bisa mencapai masa depan mereka atau tujuan yang telah mereka cita-citakan dengan lebih baik (Sumohadiningrat, 1997:165).

Untuk mewujudkan konsep dimaksud, pemberdayaan dilakukan melalui serangkaian tahapan pemberdayaan: Pertama, dengan menciptakan ambience yang kondusif bagi masyarkat atau lembaga untuk berkembang. Tahap ini dinamakan tahap enable atau enabling. Ukuran tahap ini adalah bisa mengenali bahwa sebuah masyarkat atau lembaga sudah membawa potensinya masing-masing untuk dikembangkan. Kalau tidak punya pastinya sudah larut terbawa seleksi alam sejak dulu.

Tahap Kedua, yaitu tahap empoweringnya itu sendiri, kami mengistilahkannya tahap enacting. Pada tahap ini diperlukan upaya-upaya yang lebih nyata untuk memberikan daya atau menguatkan potensi yang sudah dikenali tadi dengan wujud menyediakan fasilitas, masukan atau input sumberdaya, membangunkan akses terhadap peluang yang sekiranya dipandang akan membuat masyarakat atau lembaga ini menjadi makin berdaya.

Tahap Ketiga, memberdayakan mengandung pula arti melindungi (protecting). Pembangunan tidak harus menempuh cara-cara yang berbenturan, mengangkat yang lemah tidak harus melemahkan yang kuat (Amin, 2017). Jadi harus dipastikan terlebih dahulu bahwa dalam proses berdaya-memberdayakan ini bagaimana jangan sampai malah bertambah lemah si kelompok rentan tersebut karena kurang dayanya untuk menghadapi arus besar atau kelompok besar. Dalam rangka proteksi ini maka peran aturan yang kuat, struktur regulasi, payung hukum jelas sangat diperlukan. Pemberdayaan secanggih apapun itu tetap harus berada pada platform manajemen yang terdiri atas unsur-unsur POAC sebagaimana umumnya kegiatan manajerial yang lain (Kartasasmita, 1996:160).

Pemberdayan masjid adalah upaya memberikan daya kepada masjid sehingga dapat mencapai fungsinya yang optimal. Pemberdayan masjid terdiri dari tiga aspek pemberdayaan, yaitu sebagai berikut:

a) Idarah, yaitu manajemen masjidnya meliputi kegiatan pemberdayaan yang mencangkup kategori manajerial masjid pengadministrasian, pengorganisasian, perencanaan, pengelolaan keuangan, pengawsan, monitoring, evaluasi dan pelaporan;

b) Imarah, yaitu kemakmuran masjidnya, disini bicara tentang "ramai" nya aktivitas masjid selain fungsi ibadah juga fungsi-fungsi sosial ekonomi lainnnya ada pembangunan koperasi, fasilitas kesehatan, fasilitas c) Pendidikan, peringatan hari raya dan kegiatan sosial lainnya; dan

d) Riayah, yaitu kegiatan-kegiatan bangun-membangun fisik masjid, melengkapi fasilitas sarana prasarananya, memelihara bentuk gedung termasuk keindahan, kebersihan dan keamanan masjid.

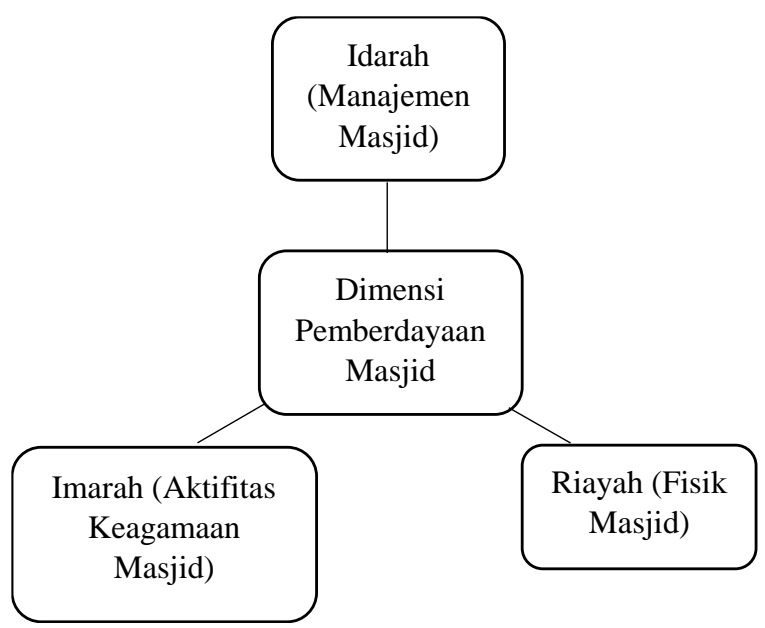

Gambar 2 Dimensi Pemberdayaan Masjid Sumber: Kepdirjen Bimas Islam Nomor DJ.II/802 Tahun 2014

\section{Metode Penelitian}

Penelitian ini merupakan penelitian dengan jenis kualitatif, yang bermaksud memahami fenomena tentang apa yang dialami oleh subjek penelitian misalnya: prilaku, persepsi, motif, tindakan secara keseluruhan dan dengan suatu konteks khusus yang alamiah dengan memanfaatkan berbagai metode ilmiah (Moleong, 2016:15).

Penelitian ini bersifat deskriptif analitik yaitu penelitian yang dilakukan untuk menghasilkan pemahaman terhadap satu fenomena yang independen dan mandiri tanpa membuat perbandingan atau pengaruh dengan fenomena yang lain.

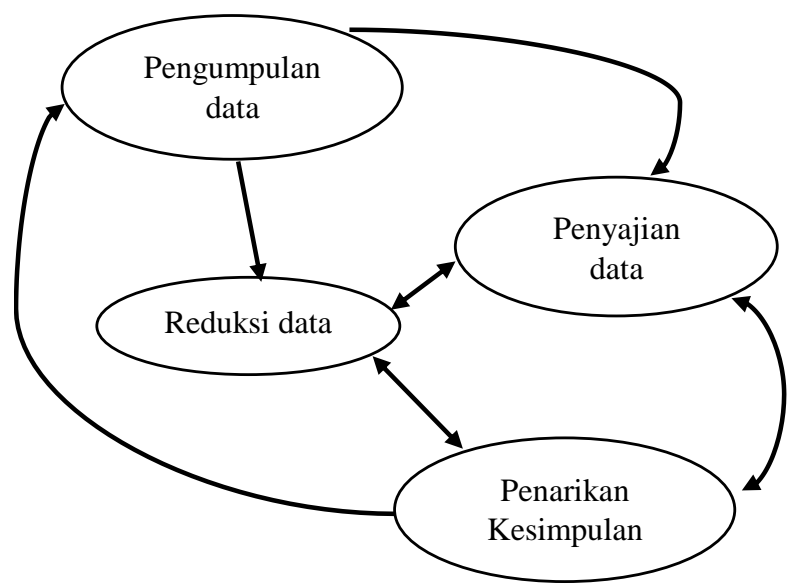

Gambar 3 Model Interaktif Miles \& Hubberman Sumber: Miles, M.B, Huberman, A.M., \& Saldana, J., 2014 
Pemilihan informan dalam penelitian ini dipilih secara sengaja (purposive) berdasarkan afiliasi organisasi dan pengalaman jabatan dari para informan. Penelitian ini menggunakan sembilan informan kunci yang berasal dari internal kementerian agama, ormas kemasjidan, ormas islam, MUI, pemuka agama/ tokoh masyarkat, dan praktisi kemasjidan.

Seluruh data yang terkumpul dilapangan yang berasal dari wawancara, dokumen dan observasi akan dianalisis menggunakan model interaktif analisis data dari Miles dan Hubberman (2014:7-9) dengan siklus seperti pada gambar 3 diatas.

\section{Hasil Penelitian dan Pembahasan}

\subsection{Analisis Unsur dan Kaitan Pembangunan Kelembagaan Masjid}

\subsubsection{Unsur Kepemimpinan}

Unsur kepemimpinan ini bisa berupa individu bisa juga sekelompok orang yang secara aktif terlibat dalam kegiatan merumuskan doktrin dan program dari lembaga kemasjidan. Kepemimpinan ini yang nantinya akan mengarahkan tindakan-tindakan dan pembangunan relasi dengan lingkungan internal maupun eksternalnya.

Kepemimpinan tidak hanya dalam kelembagaan tapi disemua konsep pemimpin, akan menjadi unsur paling kritis dalam pembangunan lembaga. Seluruh tindakan perubahan baik baru merumuskan maupun sedang melaksnakan memerlukan langkah-langkah manajerial dan hal tersebut membutuhkan keterampilan yang intensif. Pemimpin disini harus memiliki keterikatan baik dengan lembaga yang termasuk dalam kelembagaan masjid maupun lingkungan eksternalnya.

Kedudukan pemerintah sebagai ad-dhifa alghimaya (memberi perlindungan terhadap umat) dan takbiyatul ummah (memberdayakan umat) menjadikan pemerintah dalam hal ini Kemenag harus menjadi pemimpin yang menggerakkan semua unsur dalam kelembagaan masjid.

Walaupun kondisi masjid di Indonesia yang sebagian besar kepemilikannya adalah bukan milik pemerintah, dalam artian milik masyarakat, namun pemerintah tetap berkewajiban untuk melakukan pembinaan terhadap masjid-masjid tersebut.

\subsubsection{Unsur Doktrin}

Sebagai manifestasi dari values, goals dan operational-methods yang mendasari segala tindakan yang dilakukan. Doktrin dipandang sebagai sederetan tema yang memproyeksi, nantinya berwujud pada citra dan harapan dari lembaga masjid itu sendiri maupun citra yang ditangkap oleh lingkungan eksternal. Doktrin juga membingkai tentang harapan, tujuan dan tindakan dari sebuah lembaga.
Masjid sejarahnya dan hakikatnya 90\% harus melaksanakan fungsi-fungsi habluminannas, ini merupakan doktrin yang amat penting. Masjid bukan tempat pemujaan yang didalamnya dilarang melaksanakan kegiatan sosial dan relasi kemanusiaan.

Pada waktu masjid pertama kali dibangun, masjid difungsikan bukan hanya sebagai tempat shalat. Di masjid juga dilaksanakan fungsi-fungsi ekonomi (perdagangan, pasar, tempat lelang), fungsi-fungsi kepemerintahan (kantor pemerintah, baitul mal/ kantor kas negara, tempat pertemuan antar pemimpin wilayah), fungsi-fungsi pendidikan dan balai latihan masyarakat, fungsi kesehatan, rumah sakit/ klinik, bahkan sebagai tempat perhelatan seni budaya.

Takmir masjid berfungsi juga sebagai pemimpin informal dalam suatu wilayah yang ada di sekitar masjid. Selain bertanggungjawab atas penyelenggaraan urusan di dalam masjid, seorang takmir setiap harinya akan memantau kondisi masyarakat sekitar masjid. Masyarakat yang sakit atau yang lapar tanpa melihat agamanya akan diberi penanganan oleh sang takmir.

Pengertian-pengertian ini penting untuk dibangkitkan kembali di tengah kondisi masyarakat sekarang ini yang semakin terfragmentasi ke dalam urusan-urusan yang individual. Masjid dapat menjadi solusi pemberdayaan masyarakat, bila masjid dikelola secara benar dan profesional.

\subsubsection{Unsur Program}

Dengan melihat potensi masjid yang begitu besar dalam meningkatkan keberdayaan masyarakat sekitarnya, banyak pihak yang berinisiatif menciptakan program pemberdayaan masjid. Di Indonesia, tercatat dua basis lembaga non-pemerintah yang memfokuskan kerjanya pada program pemberdayaan masjid. Berbasis web/ social media: kitabisa.com, masjid nusantara.com, masjidku.id. Berbasis Ormas: Lembaga Amil Zakat (LAZ), BMT, Koperasi Islam, Dewan Masjid Indonesia (DMI), Asosiasi Nazhir-Pengembangan Wakaf Produktif, Asosiasi Takmir Masjid Indonesia, Komunitas Pecinta Masjid, Forum Ulama-Umara. Kesemuanya memiliki program-program yang bergerak di bidang pemberdayaan masjid. Tak jarang juga program satu dengan lainnya beririsan/ sama.

Dari internal Kemenag sendiri pada Subdit Kemasjidan serangkaian program juga telah diaksanakan dalam upaya pemberdayaan masjid diantaranya: penyusunan regulasi dibidang kemasjidan, pembangunan sistem data dan informasi kemasjidan (SIMAS, AMM dan Masjid Mobile), pemberian bantuan pembangunan/ rehabilitasi, pembinaan dan peningkatan kapasitas SDM kemasjidan (Takmir, Imam, dan Pengelola Aplikasi). 
Pada pelaksanaannya, program-program Kemenag banyak beririsan/ memiliki kesamaan dengan program dari organisasi non-pemerintah.

\subsubsection{Unsur Sumber Daya}

Unsur sumber daya dimaknai sebagai jenisnya sebagai berikut: memetakan kekuatan fisik yang dimiliki lembaga, keuangan, SDM, keterlibatan teknologi dan fungsi kehumasan dari lembaga kemasjidan. Sumber daya bukan hanya sampai ke memetakan apa-apa saja (mengabsen) namun termasuk pada persoalan jaminan (guarantee) atas ketersediaan keuangan, SDM, keterlibatan teknologi dan fungsi kehumasan dari lembaga kemasjidan pada waktu yang tepat dan jumlah yang tepat (keandalan).

Walaupun bukan satu-satunya sumberdaya yang diperlukan dalam organisasi, namun dana-dana sangat diperlukan untuk membiayai fasilitas dan peralatan maupun operasi-operasi yang sedang berlangsung. Sumber-sumber apapun yang menyediakan dana penjualan produk-produk, anggaran-anggaran baik tingkat nasional maupun tingkat daerah, sumbangansumbangan sukarela, atau bantuan luar negeri kepemimpinan harus bekerja untuk memenuhi harapanharapan dan melayani permintaan-permintaan yang menjamin aliran dana yang dapat diandalkan dan harus melakukan demikian tanpa mengorbankan tujuan-tujuan inovatif yang kritis dari organisasi tersebut.

Peluang kerjasama pemerintah dengan swasta terjadi pada dimensi Imarah, dewan kemakmuran masjid berkesempatan untuk menghidupkan fungsi masjid dalam hal pemanfaatan untuk kebutuhan sosial kemasyarakatan seperti pembangunan fasillitas pendidikan, fasilitas ekonomi, perdagangan, fasilitas kesehatan dan fasilitas sosial lainnya sepanjang tidak dilarang secara syari'ah.

\subsubsection{Unsur Struktur Internal}

Unsur struktur internal yang meliputi struktur dan SOP untuk bekerjanya lembaga masjid harus juga dapat dipetakan tentang pembagian-pembagian peran, pembagian kewenangan, pola-pola komunikasi, sistem proses bekerja lembaga termasuk kepatuhan anggota terhadap doktrin dan juga program lembaga. Pada tingkat pusat urusan kemasjidan dilaksanakan oleh struktur seperti yang tergambar pada gambar 4 .

Kendala terjadi distruktur daerah. Berdasarkan PMA 13 Tahun 2014 tentang Struktur Instansi Vertikal Kementerian Agama; pelaksana fungsi-fungsi kemasjidan di daerah dilaksanakan pada tingkat provinsi oleh Bidang Urais Binsyar, pada tingkat kab/ kota dilaksanakan oleh Seksi Urais Binsyar dan pada tingkat kecamatan oleh pelaksana urusan Bimas Islam di KUA. Namun pembagian ini tidak berlaku bagi seluruh provinsi, kab/ kota dan kecamatan di indonesia.
Pada beberapa provinsi, kab/ kota, dan kecamatan dengan jumlah penduduk muslim dan jumlah masjid yang

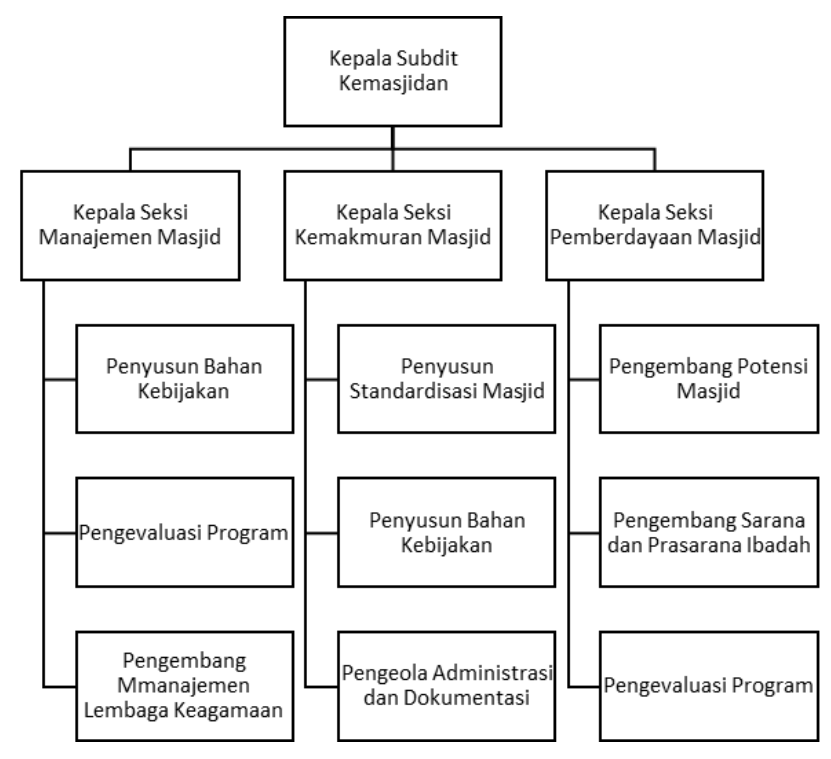

Gambar 4 Struktur Subdit Kemasjidan pada Ditjen Bimas Islam

Sumber: Ditjen Bimas Islam, 2015

sedikit, struktur Urais Binsyar digabung dengan urusan Bimas Islam yang lain seperti penerangan agama, pemberdayaan KUA, Halal, dan Zakat Wakaf. Hal demikian yang membuat pelaksanaan program-program kemasjidan didaerah belum menjadi prioritas program. Bahkan ada beberapa provinsi seperti NTB, NTT, Papua dan Papua Barat, pelaksanaaan bidang kemasjidan tidak hanya melebur pada bidang Bimas Islam saja tapi juga bidang Penyelenggaraan Haji. Dengan telaahan ini mustahil untuk "menitipkan" target yang seragam bagi pencapaian program-program kebimasislaman tidak hanya program kemasjidan.

\subsection{Analisis Kaitan pada Kelembagaan Masjid}

Beberapa pemimpin lebih tertarik dan lebih efektif dalam manajemen intern organisasi-organisasinya daripada dalam membina hubungan-hubungan eksternalnya. Namun, kepemimpinan lembaga yang efektif memerlukan perhatian yang sekaligus untuk membangun organisasi tersebut dan untuk mengelola hubungan-hubungan lingkunganya. Tiap organisasi ikut serta dalam jaringan interaksi dengan organisasiorganisasi yang lainnya.

Organisasi yang inovatif mempersoalkan dirinya untuk memperoleh dukungan dan mengatasi perlawanan dan untuk menghasilkan perubahan-perubahan dalam organisasi-organisasi lainnya dengan mana ia mengadakan interaksi. Jaringan hubungan-hubungan inter-organisatoris ini dinyatakan sebagai kaitan.

Sembilan organisasi yang terdiri dari unsur-unsur sebagai berikut: Masyarakat Umum, Assosiasi Profesi Masjid (Takmir, Khatib, Imam), Ormas Islam, Ormas 
Masjid, Lembga Donor/ Perbankan, Koerasi, Lembag Negara lainnya, (K/L, DPR, Bappenas), Kemenag, Pemerintah Daerah terkait satu dengan yang lain. Bersatu dalam kelembagaan masjid masing-masing organisasi tersebut sudah melakukan upaya pemberdayaannya masing-masing, mereka sudah bergerak (harakah), akan tetapi koordinasi gerakannya belum tercipta (tansyik harakah). Ketidakadaan koordinasi gerakan ini menyebabkan banyak program yang telah diluncurkan belum mampu menyelesaikan persoalan-persoalan masjid.

Analisis kaitan terdiri dari empat jenis kaitan, yaitu: Kaitan yang memungkinkan (enabled), Kaitan functional, Kaitan Normative, dan Kaitan Scattered. Dalam kelembagaan masjid, kaitan dengan Kemenag (pusat beserta instansi vertikalnya), Pemerintah Daerah (prov, kab.kota, kecamatan, kelurahan/ desa), Dewan Masjid Indonesia (DMI), Majelis Ulama Indonesia sumberdaya yang diperlukan oleh kelembagaan masjid untuk berfungsi.

Selanjutnya kaitan dengan lembaga donor, komunitas-komunitas filantropi, perbankan syariah, koperasi dan BMT, lembaga-lembaga amil zakat, koperasi dan organisasi wakaf produktif dikategorikan dalam kaitan fungsional. Selain mengendalikan alokasi sumberdaya, kaitan fungsional juga yang nantinya akan menggunakan output dari kelembagaan masjid menjadi input pada organisasinya.

Kemudian pada kategori kaitan selanjutnya, kaitan dengan lembaga legislatif (DPR, DPRD, DPD), dan kaitan dengan $\mathrm{K} / \mathrm{L}$ diluar Kemenag (Kemendagri, Kemenlu, Kemenkeu, Bappenas, Kemenkes, BPN) dikategorikan sebagai kaitan tersebar yang tidak bisa kita identifikasi keanggotaannya dalam organisasi formal pada kelembagaan masjid namun memiliki kaitan dengan unsur-unsur di dalam kelembagaan masjid tersebut.

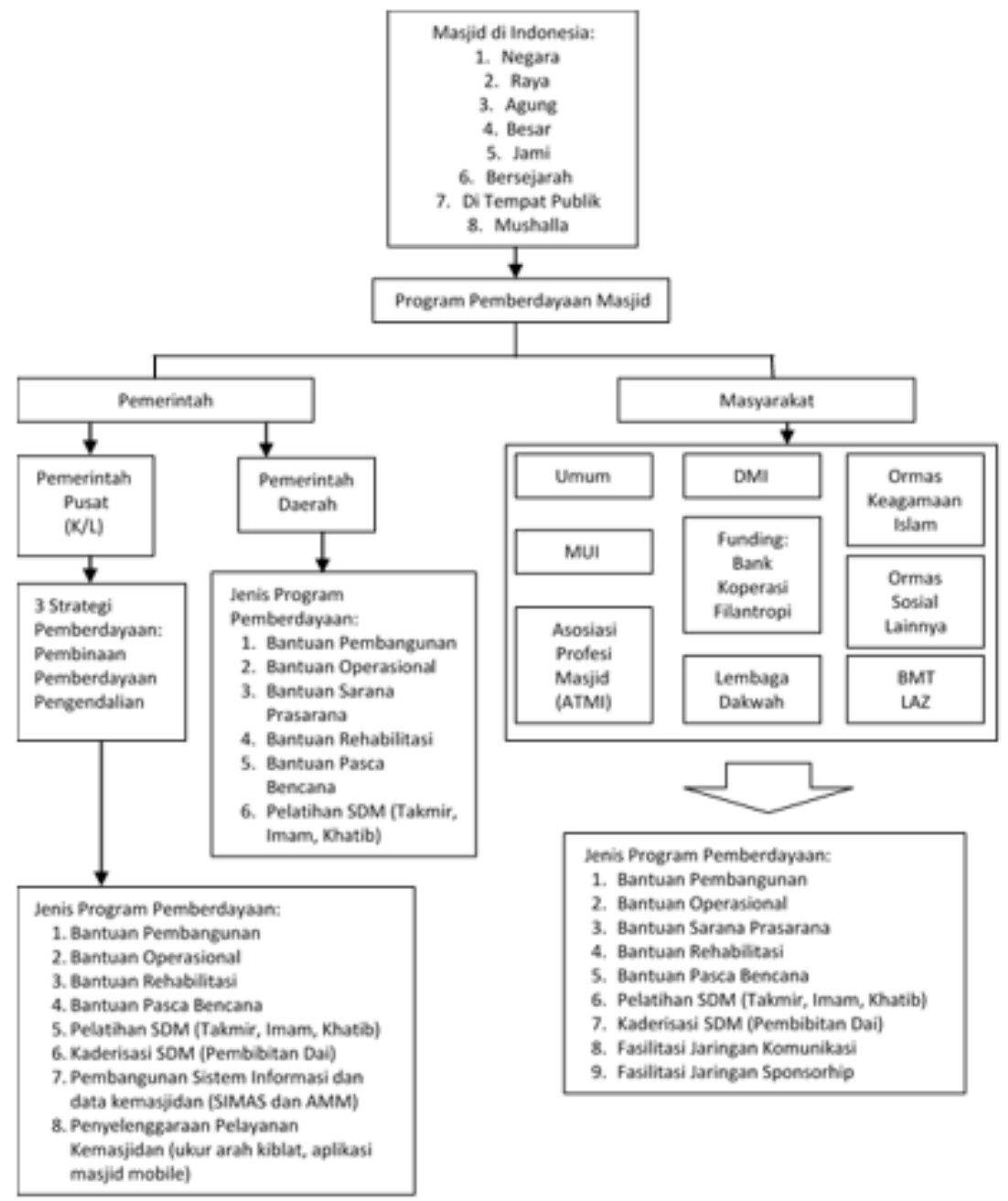

Gambar 5 Existing Model Pemberdayaan Masjid di Indonesia Sumber: Hasil analisis. 2018

(MUI) dan asosiasi-asosiasi profesi kemasjidan dikategorikan sebagai kaitan yang memungkinkan, karena kelompok-kelompok sosial inilah yang mengendalikan alokasi wewenang dan sumber-
Bila digambarkan dalam bentuk diagram alur, polapola kelembagaan masjid dapat digambarkan seperti pada gambar 5 diatas. 


\subsection{Analisis Tahap Pemberdayaan Masjid dalam Tinjauan Pembangunan Kelembagaan}

Masjid nyatanya sebagai sebuah kelembagaan memiliki potensi menjadi resources dalam strategi pembangunan masyarakat (dalam arti sempit) dan pembangunan negara (dalam arti luas). Namun hal ini dapat dicapai ketika semua unsur bersatu padu mensinergikan kapasitas dari masing-masing organisasi yang terlibat dalam kelembagaan masjid menjadi satu tansyik harakah atau koordinasi gerakan mencapai tujuan pemberdayaan masjid.

Dalam upaya itu, strategi pemberdayan harus diarahkan pada dua siasat, yaitu Pertama, memberi bimbingan, pendampingan agar masjid sebagai organisasi dapat memandirikan dirinya terlebih dahulu, karena kemandirian masjid sebagai organisasi adalah modal untuk memberdayakan pada tahap selanjutnya. Mandiri disini termasuk bagaimana masjid-masjid itu dapat meningkatkan produktivitasnya dengan mengoptimalkan kapasitas yang ada pada organisasi masjid itu sendiri terlebih dahulu. Kedua, baru mengaktifkan kelembagaannya, meningkatkan kapasitas dan kemampuan seluruh unsur yang ada dalam kelembagaan masjid untuk bersatupadu membangun masjid sesuai dengan kapasitasnya masing-masing dalam peran apa dalam fungsi yang bagaimana dengan sumberdaya yang seberapa dan sebagainya (Kartasasmita, 1996:158).

Dalam kerangka pikiran itu, upaya memberdayakan masjid akan kami arahkan ke dalam tiga tahapan: Pertama, tahap enable atau enabling. Ukuran tahap ini adalah bisa mengenali bahwa sebuah masyarkat atau lembaga sudah membawa potensinya masing-masing untuk dikembangkan. Tahap Kedua, yaitu tahap empowering, yaitu tahapan dimana semua organisasi yang terikat dalam kelembagaan masjid memberikan daya atau menguatkan potensi yang sudah dikenali tadi dengan wujud menyediakan fasilitas, masukan atau input sumberdaya, membangunkan akses terhadap peluang yang sekiranya dipandang akan membuat masyarakat atau lembaga ini menjadi makin berdaya. Tahap Ketiga, yaitu tahap melindungi (protecting) dimana dalam rangka proteksi ini maka peran aturan yang kuat, struktur regulasi, payung hukum jelas sangat diperlukan.

\subsubsection{Tahap Enabling}

Kondisi Masjid di Indonesia saat ini, secara umum fakta dilapangan menunjukkan bahwa disatu sisi, kuantitas berdasarkan data mengalami kemajuan pesat sejak 2010. Namun, harus diakui secara kualitatif dari sisi pemberdayaan, fungsi masjid yang banyak itu (fungsi sosialnya) semakin hari akan semakin menyempit. Dikhawatirkan oleh banyak pihak (Ayub (1996), Gazalba (1983), Mas'ud dalam Farida (2013), Yani (2016)); bila dibiarkan seperti ini lama-kelamaan fungsi masjid hanya tinggal untuk shalat. Itupun sepi, jarang yang shalat dimasjid karena shalat bisa dilakukan dimana saja. Masjid tidak lagi ada kaitannya dengan persoalanpersoalan kemasyarakatan secara luas.

Prinsip integrasi ajaran Islam, yaitu doktrin bahwa hubungan dengan Allah harus seimbang dengan hubungan perbuatan baik dengan manusia dan sesama makhluk didunia akan semakin terpecah. Masjid hanyalah sebagai tempat yang "sekali-sekali" dikunjungi, dikelola seadanya, tidak diberdayakan, dan tidak menjadi solusi atas problematika kemasyarakatan yang bersifat keumatan.

\subsubsection{Tahap Enacting}

Terdapat tiga langkah startegis yang telah dilakukan oleh pemerintah untuk meningkatkan kualitas masjid, antara lain: a) Regulasi dan Standar; b) Pembinaan dan Pmberdayaan; serta c) Datum dan Informasi. Rencana Strategis Kementerian Agama Tahun 2009-2014 diantaranya menggarisbawahi kebijakan Kemenag pada peningkatan kualitas kehidupan beragama, dengan sasaran terwujudnya suatu kondisi keberagamaan masyarakat yang dinamis dan mampu mendukung percepatan pembangunan nasional (Kementrian Agama RI, 2009). Program pemberdayaan masjid yang tercantum dalam Renstra dimaksud mengindikasikan bahwa masjid dapat menjadi basis perubahan sosial, menuju kesalehan individu, dan kesalehan sosial. Tidak hanya itu, masjid juga dapat berfungsi sebagai tempat pendidikan umat, informasi, kebudayaan bahkan dapat juga menjadi pusat pengembangan ekonomi Islam, sehingga konsep pemberdayaan ekonomi pun bisa dilahirkan dari aktivitas umat dimasjid.

Perihal rumah ibadah yang diatur oleh pemerintah Indonesia tidak hanya sebatas ijin pendirian saja, namun kelengkapan sarana prasarana, keamanan dan kenyamanan umat beragama dalam beribadah, layak atau tidaknya bangunan rumah ibadah, rasio rumah ibadah dengan penduduk sekitar hingga pemberdayaan rumah ibadah juga menjadi tanggung jawab Kemenag.

\subsubsection{Tahap Protecting}

Untuk mengetahui sejuhmana upaya proteksi yang harus dilakukan pemerintah dalam upaya memberdayakan masjid maka sebelum masuk proses itu perlu terlebih dahulu mengenal kondisi saat ini tentang kekuatan/ potensi yang kita miliki serta kelemahan/ keterbatasan kita dan peluang-peluang/ kesempatan yang terbuka diimbangi dengan ancaman yang muncul dari luar (eksternal).

Upaya protecting juga dilakukan dengan menerbitkan serangkaian regulasi tentang kemasjidan. Pada penelitian ini, peneliti berhasil menginventarisir regulasi dalam bidang kemasjidan yang terbit sejak Tahun 1969, yaitu sebagai berikut: 
Tabel 2 Inventarisasi Regulasi di Bidang Kemasjidan

\begin{tabular}{|c|c|c|}
\hline No & Regulasi & Tentang \\
\hline 1 & $\begin{array}{l}\text { SKB Menag dan } \\
\text { Mendagri Nomor } \\
\text { 01/BER/mdn- } \\
\text { mag/1969 }\end{array}$ & $\begin{array}{l}\text { Pelaksanaan Tugas } \\
\text { Aparatur Pemerintahan } \\
\text { dalam Menjamin } \\
\text { Ketertiban dan Kelancaran } \\
\text { Pelaksanaan } \\
\text { Pengembangan dan Ibadat } \\
\text { Agama oleh Pemeluk- } \\
\text { Pemeluknya }\end{array}$ \\
\hline 2 & $\begin{array}{l}\text { Instruksi Dirjen } \\
\text { Bimas Islam Nomor } \\
\text { Kep/D/101/1978 } \\
\end{array}$ & $\begin{array}{l}\text { Tuntunan Penggunaan } \\
\text { Pengeras Suara di Masjid } \\
\text { dan Mushalla }\end{array}$ \\
\hline 3 & $\begin{array}{l}\text { UU Nomor } 28 \text { Tahun } \\
2002\end{array}$ & Bangunan Gedung \\
\hline 4 & $\begin{array}{l}\text { KMA Nomor } 394 \\
\text { Tahun } 2004\end{array}$ & $\begin{array}{l}\text { Penetapan Status Masjid } \\
\text { Wilayah }\end{array}$ \\
\hline 5 & $\begin{array}{l}\text { PMA Nomor } 54 \\
\text { Tahun } 2006\end{array}$ & $\begin{array}{l}\text { Susunan Organisasi dan } \\
\text { Tata Kerja Badan } \\
\text { Kesejahteraan Masjid }\end{array}$ \\
\hline 6 & $\begin{array}{l}\text { PP Nomor } 36 \text { Tahun } \\
2005\end{array}$ & $\begin{array}{l}\text { Peraturan Pelaksanaan UU } \\
\text { Nomor } 28 \text { Tahun } 2002 \\
\text { Tentang Bangunan } \\
\text { Gedung }\end{array}$ \\
\hline 7 & $\begin{array}{l}\text { PBM Menag dan } \\
\text { Mendagri Nomor } 8 \\
\text { dan } 9 \text { Tahun } 2006\end{array}$ & $\begin{array}{l}\text { Pedoman Pelaksanaan } \\
\text { Tugas Kepala } \\
\text { Daerah/Wakil Kepala } \\
\text { Daerah dalam } \\
\text { Pemeliharaan Kerukunan } \\
\text { Umat Beragama, } \\
\text { Pemberdayaan FKUB dan } \\
\text { Pendirian Rumah Sakit }\end{array}$ \\
\hline 8 & $\begin{array}{l}\text { Buku Panduan } \\
\text { Tipologi Masjid } 2008\end{array}$ & Tipologi Masjid \\
\hline 9 & $\begin{array}{l}\text { Kepdirjen Bimas } \\
\text { Islam Nomor DJ } \\
\text { II/802 Tahun } 2014 \\
\end{array}$ & $\begin{array}{l}\text { Standar Pembinaan } \\
\text { Manajemen Masjid }\end{array}$ \\
\hline 10 & $\begin{array}{l}\text { Instruksi Dirjen } \\
\text { Bimas Islam Nomor } \\
\text { DJ II/461 Tahun } 2014\end{array}$ & $\begin{array}{l}\text { Penerapan Sistem } \\
\text { Informasi Masjid pada } \\
\text { Kanwil Kemenag Provinsi } \\
\text { dan Kab./Kota }\end{array}$ \\
\hline 11 & $\begin{array}{l}\text { Edaran Direktur Urais } \\
\text { DT } \\
\text { II/3/HM.01/786/2015 }\end{array}$ & $\begin{array}{l}\text { Kegiatan tentang Standar } \\
\text { Pembinaan Masjid } \\
\text { Berbasis SIMAS }\end{array}$ \\
\hline 12 & $\begin{array}{l}\text { Kepdirjen Bimas } \\
\text { Islam Nomor DJ } \\
\text { III/384 Tahun } 2016\end{array}$ & $\begin{array}{l}\text { Juknis Penilaian dan } \\
\text { Penetapan Masjid Besar } \\
\text { Percontohan Tingkat } \\
\text { Nasional }\end{array}$ \\
\hline 13 & $\begin{array}{l}\text { Edaran Direktur Urais } \\
\text { B 1852/Dt.III } \\
\text { 1/3/HM.01/07/2016 }\end{array}$ & $\begin{array}{l}\text { Penilaian dan Penetapan } \\
\text { Masjid Besar Percontohan } \\
\text { Nasional Tahun } 2016\end{array}$ \\
\hline 14 & $\begin{array}{l}\text { Kepdirjen Bimas } \\
\text { Islam Nomor } 582 \\
\text { Tahun } 2017\end{array}$ & $\begin{array}{l}\text { Penetapan Standar Imam } \\
\text { Tetap Masjid }\end{array}$ \\
\hline 15 & $\begin{array}{l}\text { Edaran Dirjen Bimas } \\
\text { Nomor } \\
\text { B.829/DJ.III/HM.00/0 } \\
\text { 2/2018 }\end{array}$ & $\begin{array}{l}\text { Pengamanan Masjid dan } \\
\text { Mushalla }\end{array}$ \\
\hline
\end{tabular}

Sumber: Hasil analisis, 2018

Berdasarkan analisis strategi pemberdayaan sebagaimana telah diuraikan pada bagian 4.2, penelitian ini menghasilkan model yang direkomendasikan untuk

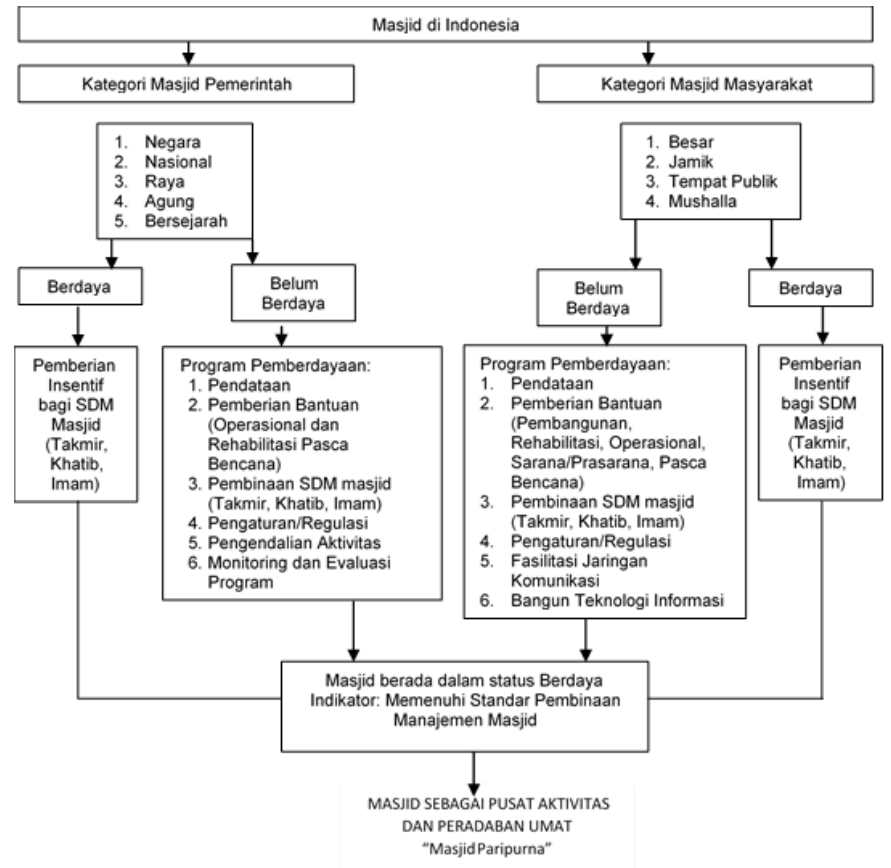

Gambar 6 Rekomendasi Model Pemberdayaan Masjid di Indonesia

Sumber: Hasil Analisis, 2018

upaya pemberdayaan masjid di Indonesia yang dapat digambarkan dalam diagram alur sebagai berikut:

\section{Kesimpulan}

Arah yang tidak terarah telah menyebabkan upaya pemberdayaan masjid-masjid dan mushalla di Indonesia yang selama ini dilakukan oleh Kemenag menjadi tumpang tindih dengan upaya pemberdayan yang dilakukan oleh unsur-unsur kaitan. Semua pihak berfokus pada harakah namun tidak pada tansyik harakahnya (koordinasi gerak).

Grand Design Nasional Pemberdayaan Masjid 2020-2040 yang dirumuskan dalam tahap-tahap jangka menengah 5 tahunan dalam bentuk Rencana strategis dapat menjadi solusi dari tidak berfungsinya peta perencanaan program-program kemasjidan selama ini.

Rencana Strategis perlu dilengkapi dengan indikator keberhasilan yang SMART (Specific, Measureable, Acurate, Reliable, Time Bound) dan disepakati oleh seluruh personil yang terikat dalam kelembagaan masjid (asas keterwakilan). Indikator keberhasilan dapat menjadi starting point untuk melakukan penilaian dan evaluasi atas performa kerja pemerintah dan dapat menjadi guide bagi para stakeholder untuk melakukan monitoring atas kinerja pemerintah.

\section{Daftar Pustaka}

Amin, Ma'ruf, (2017). Solusi Hukum Islam (Makharij Fiqhiyyah) sebagai Pendorong Arus Baru 
Ekonomi Syariah di Indonesia. Orasi Ilmiah, Pengukuhan Guru Besar Bidang Ilmu Ekonomi Muamalat Syariah, UIN Maliki, Malang. Kemenag, Jakarta.

Ayub, M. E. (1996). Manajemen Masjid. Jakarta: Gema Insani Press.

Bratakusumah, Deddy Supriady \& Riyadi. (2005). Perencanaan Pembangunan Daerah. Jakarta: PT. Gramedia Pustaka Utama.

Esman, J Milton. (1986). Pembangunan Lembaga dan Pembangunan Nasional dari Konsep ke Aplikasi. Unsur-Unsur dari Pembangunan Lembaga (Penerjemah Guritno P. dan Aldi Jeni). Jakarta: UI-Press.

Farida, dkk. (2013). Transformasi Sosial Masjid dalam Pusaran Peradaban: Sebuah Hasil Penelitian. Jakarta: Balai Litbang Agama.

Gazalba, Sidi, (1983). Mesjid Pusat Ibadat dan Kebudayaan Islam, Cetakan IV. Jakarta: Pusaka Antara.

Haryono, Bambang Santoso. (2012). Capacity Building. Malang: UB Press.

Iglesias, Gabriel. (1976). Implementation and the Planning of Development: Notes on Trends and Issues Focussing on the Concept of Administrative Capability', in Implementation: The Problem of Achieving Results: A Casebook on Asian Experiences, ed. Gabriel U. Iglesias. Manila: Eastern Regional Organization for Public Administration.

Kartasasmita, Ginanjar. (1996). Pembangunan Untuk Rakyat: Memadukan Pertumbuhan dan Pemerataan. Jakarta: CIDES.

Kementrian Agama Republik Indonesia. (2016). Bimas Islam Dalam Angka Tahun 2015. Jakarta: Kemenag RI.

Kementrian Agama Republik Indonesia. (2009). Rencana Strategis Kementrian Agama Tahun 2010-2013. Jakarta: Kementrian Agama RI.

Kepdirjen Bimas Islam Nomor DJ.II/802 Tahun 2014 tentang Standar Pembinaan Manajemen Masjid.

Machendrawati, Nanik. (2001). Pengembangan Masyarakat Islam. PT Remaja Posdakarya, Bandung.

Mindarti, Lely Indah. (2007). Revolusi Administrasi Publik, Aneka Pendekatan dan Teori Dasar. Malang: Bayumedia.

Moleong, Lexy. (2016). Metodologi Penelitian Kualitatif Edisi Revisi. Bandung: Remaja Rosdakarya.

Miles, Matthew B., A. Michael Huberman., \& Johnny Saldana. (2014). Qualitative Data Analysis: A Methods Sourcebook. Thousand Oaks, CA: Sage.

Mubyarto. (2000). Membangun Sistem Ekonomi. BPFEUGM, Yogyakarta.
Siagian, S.P. (1994). Manajemen Modern: Bunga Rampai. CV. Masagung, Jakarta.

Sumodiningrat. (1997). Pembangunan Daerah dan Pemberdayaan Masyarakat. PT. Bina Rena Pariwara, Jakarta

Tikson, Deddy. (2005). Keterbelakangan dan Ketergantungan, Teori Pembangunan di Indonesia, Malaysiah dan Thailand. Ininnawa, Makassar.

Yani, Ahmad. (2016). Panduan Memakmurkan Masjid. Depok: Al-Qalam. 